\title{
FIRST RECORD OF PO BROOK LAMPREY, LETHENTERON ZANANDREAI (CEPHALASPIDOMORPHI: PETROMYZONTIFORMES: PETROMYZONTIDAE), IN THE HUTOVO BLATO WETLAND, BOSNIA AND HERZEGOVINA
}

\author{
Pero TUTMAN ${ }^{1 *}$, Jakov DULČIĆ ${ }^{1}$, and Branko GLAMUZINA ${ }^{2}$ \\ ${ }^{1}$ Institute of Oceanography and Fisheries, P.O. Box 500, 21000 Split, Croatia \\ ${ }^{2}$ University of Dubrovnik, Department for Aquaculture, Ćira Carića 4, 20000 Dubrovnik, Croatia
}

Tutman P., Dulčić J., Glamuzina B. 2009. First record of Po brook lamprey, Lethenteron zanandreai (Cephalaspidomorphi: Petromyzontiformes: Petromyzontidae), in the Hutovo Blato wetland, Bosnia and Herzegovina. Acta Ichthyol. Piscat. 39 (1): 55-58.

\begin{abstract}
On 14 July 2007 two metamorphosed males of the Po brook lamprey, Lethenteron zanandreai (Vladykov, 1955), were caught in the Hutovo Blato wetland, Neretva River basin (Adriatic Sea watershed) in Bosnia and Herzegovina. This is the first report on the occurrence of this species in the waters of Bosnia and Herzegovina. New evidence of their original distributional range extended eastward is presented.
\end{abstract}

Keywords: Po brook lamprey, Lethenteron zanandreai, Adriatic watershed, Hutovo Blato wetland, BosniaHerzegovina, first record

The Po brook lamprey, Lethenteron zanandreai (Vladykov, 1955), is a non-parasitic lamprey endemic for the area extending from the Alpine watershed of the northern and Adriatic slope of central Italy (Bianco 1992, 1995) to the Adriatic drainage basin of Slovenia (Povž 1995) and Croatia (Holčík and Mrakovčić 1997). It lives up to 6 years. This short-lived lamprey exclusively occurs in clean, cold waters usually near springs in the foot-hill zone, over muddy or sandy bottom. Ammocoetes are filtering bottom-feeders. Their digestive system degenerates shortly after metamorphosis, which takes place after 4.5 years (Bianco 1986), while during the adult phase individuals do not feed. Reproduction takes place from January to June and after spawning lampreys die (Bianco 1986). This endangered species is listed in Annexes II and V of the Habitat Directive 92/43 of EC, and in Appendix II and III of the Bern Convention. From the zoogeographical point of view, the Holarctic family Petromyzontidae includes very interesting species that have a basal position in the vertebrate phylogenetic tree (Tagliavini et al. 1994). $L$. zanandreai is one of a few remaining near-primary freshwater fishes (Bianco and Miller 1990) which has escaped trans-introductions and for this reason may be considered as a valuable biogeographical indicator (Bianco 1992). The present distributional range indicate their origin by relatively ancient colonization events, dispersal and/or exchange of freshwater fishes, that occurred probably during the last glacial (Würm) extend- ed phase of the River Po basin (Bianco and Miller 1990, Bianco 1992).

The Po brook lamprey has previously not included in the list of freshwater ichthyofauna of Bosnia and Herzegovina (Vuković 1977). This paper confirms the occurrence of L. zanandreai in the waters of Bosnia and Herzegovina, and expands its distribution area more eastward.

The Hutovo Blato wetland is one of the most important parts of the Neretva River delta in Bosnia and Herzegovina (Fig. 1). It is situated $20 \mathrm{~km}$ inland from the Adriatic Sea, along the borders with Croatia. This area, covering $74 \mathrm{~km}^{2}$, was proclaimed a Natural Park in 1995 and listed in the Ramsar Convention as an internationally protected wetland in 2001. There are six small lakes in the park, namely: Škrka, Jelim, Drijen, Orah, Deran, and Donje Blato, the latter being an accumulation lake. The Krupa, a $10 \mathrm{~km}$ long karstic river, connects Lake Deran with the Neretva River. The altitudinal range of the area is about $3 \mathrm{~m}$. The ichthyofauna of the Hutovo blato wetland comprises a highly diverse fish community composed of 22 species representing 20 genera and 12 families (Glamuzina et al. 2002). Eight species (36.4\%) are endemic (Tutman et al. 2002).

On 14 July 2007, two metamorphosed males of L. zanandreai (Fig. 2) were captured by elecrofishing in the Hutovo Blato wetland (Deran and Orah lakes) at a depth of $0.1 \mathrm{~m}$ in muddy substrate and water temperature of $14.4^{\circ} \mathrm{C}$. Terminology, symbols, and measure-

\footnotetext{
${ }^{*}$ Correspondence: Dr. Sc. Pero Tutman, Institut za oceanografiju i ribarstvo, POB 500, Šetalište Ivana Meštrovića 63, 21000 Split, Croatia, phone: (+385) 21 408 030, fax: (+385) 358 650, e-mail: tutman@izor.hr
} 


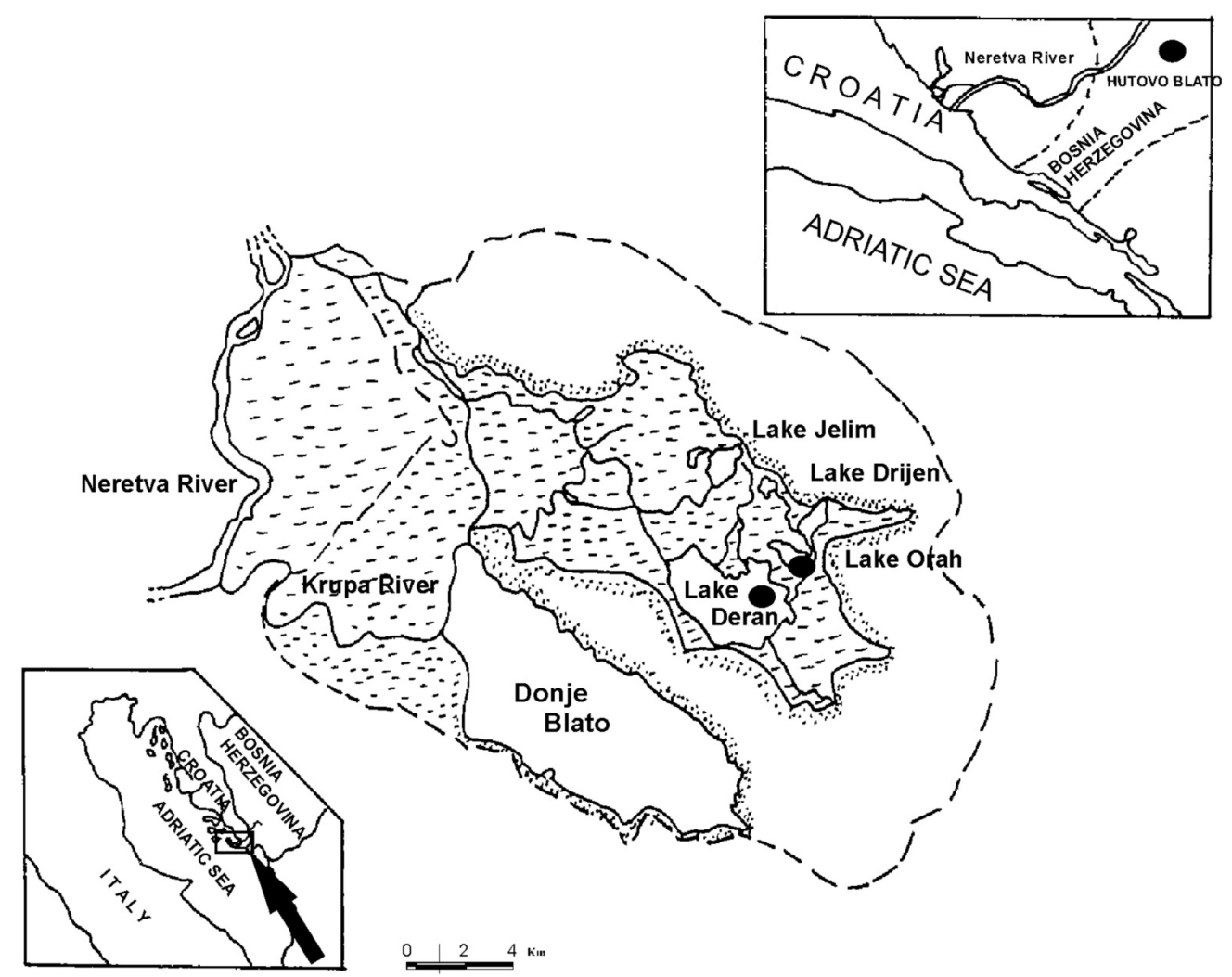

Fig. 1. Map of Hutovo Blato wetland (Bosnia and Herzegovina), indicating locations of Lethenteron zanandreai captures

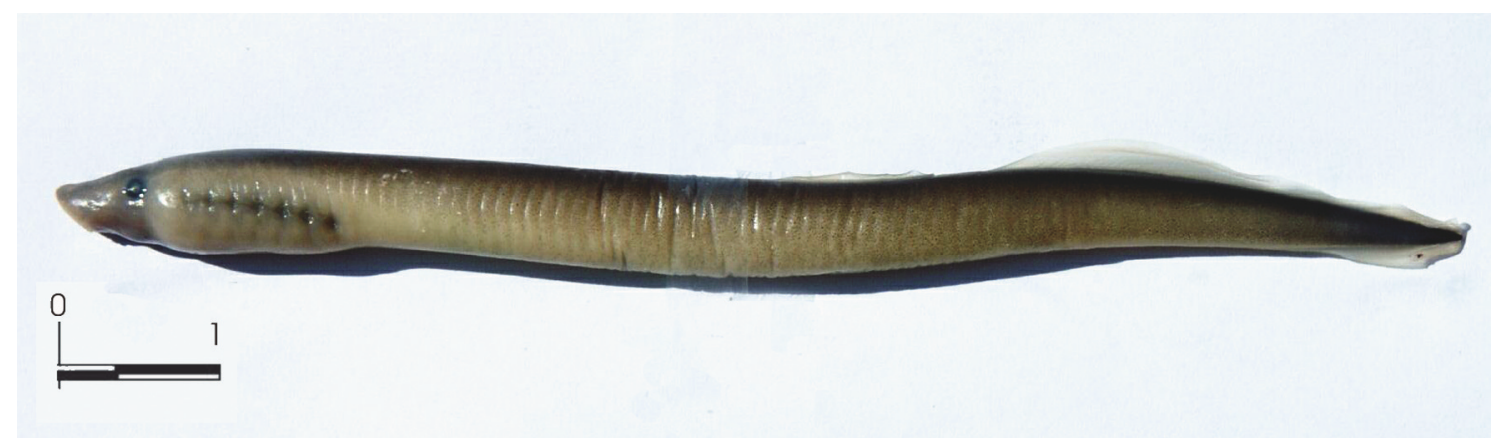

Fig. 2. Po brook lamprey, Lethenteron zanandreai $(T L=127 \mathrm{~mm})$, caught on 14 July 2007 in the Hutovo Blato wetland

ments are in accordance with Vladykov (1955) and Vladykov and Follett (1967), as summarized and explained by Holčík (1986). Measurements were taken on the left side of each specimen using a mechanical callipers to $0.1 \mathrm{~mm}$.

Morphometric measurements and meristic characteristics of the specimens caught are presented in Table 1. All values and general morphology are in agreement with those found by Holčík and Mrakovčić (1997) in populations inhabiting Croatian part of Neretva River basin.

The distribution of $L$. zanandreai in Italian freshwaters have been summarized in Bianco (1995). Initially, this species was known to have a limited geographical distribution (Bianco 1986), confined mostly to the River Po basin. Reports on its occurrences southward in the rivers Potenza and Esino in central Italy (Bianco 1992) and northward in Soča and Vipava rivers, as well as in the
Adriatic drainage basin of Slovenia (Povž 1995) extended its distribution range. Holčik and Mrakovčić (1997) extended the species distribution further southward by reporting its occurence in Croatian rivers of the Adriatic drainage basin (Neretva and Matica rivers). The presence of $L$. zanandreai in Hutovo Blato wetland is probably linked with the populations in the nearby rivers Neretva and Matica in Croatia and provides new evidence of range extension, indicated by Bianco (1992).

From the zoogeographical point of view, this extension of the species distribution range, as refered by Bianco (1992) and later by Holčík and Mrakovčić (1997), may be explained by the dispersal and/or exchange of freshwater fishes during the last glacial (Würm) extended phase of the river Po, although Tagliavini et al. (1994) sets that in the Pleistocene. Consequently, the present distribution of such 'primary-like' freshwater fishes in Mediterranean 
Morphometric (in mm) and meristic counts of Lethenteron zanandreai specimens from the Hutovo Blato wetland, Bosnia and Herzegovina

\begin{tabular}{|c|c|c|c|}
\hline & \multirow{2}{*}{ Character } & \multicolumn{2}{|c|}{ Value $[\mathrm{mm}]$} \\
\hline & & specimen 1 & specimen 2 \\
\hline \multirow{9}{*}{$\begin{array}{l}.0 \\
0 \\
0 \\
0 \\
0 \\
0 \\
\Sigma \\
\Sigma\end{array}$} & Total length $(\mathrm{Tl})$ & 127 & 105 \\
\hline & In $\%$ of $T L:$ & & \\
\hline & Prebranchial length $\left(\mathrm{d}-\mathrm{B}_{1}\right)$ & 15.3 & 11.2 \\
\hline & Branchial length $\left(\mathrm{B}_{1}-\mathrm{B}_{7}\right)$ & 12.1 & 9.9 \\
\hline & Trunk length $\left(\mathrm{B}_{7}-\mathrm{a}\right)$ & 53.1 & 49.2 \\
\hline & Tail length $(\mathrm{a}-\mathrm{C})$ & 26.8 & 22.5 \\
\hline & Disc length $(\mathrm{d})$ & 6.2 & 5.2 \\
\hline & Preocular length $(\mathrm{d}-\mathrm{O})$ & 7.8 & 6.7 \\
\hline & Second dorsal fin height $\left(\mathrm{HD}_{2)}\right.$ & 4.1 & 3.8 \\
\hline \multirow{11}{*}{$\frac{0}{\sum_{0}^{0,0}}$} & Number of trunk myomeres (TM) & 53 & 53 \\
\hline & Number of velar tentacles (VT) & 3 & 3 \\
\hline & Supraoral lamina (SO) & 2 & 2 \\
\hline & Infraoral lamina (IO) & 5 & 5 \\
\hline & Anterior (circumoral) teeth (AC) & 1 & 1 \\
\hline & First row of anterial (circumoral) teeth $\left(\mathrm{AC}_{1}\right)$ & 5 & 4 \\
\hline & Posterial teeth (PC) & 0 & 0 \\
\hline & First row of posterial (circumoral) teeth $\left(\mathrm{PC}_{1}\right)$ & 0 & 0 \\
\hline & Exolateral teeth $(\mathrm{Ex})$ & 0 & 0 \\
\hline & Endolateral teeth (En) & $\begin{array}{c}2-2-1(2) \\
2-2-2\end{array}$ & $\begin{array}{c}2-2-1(2) \\
2-2-2\end{array}$ \\
\hline & Transverse lingual lamina (TL) & 6 & 6 \\
\hline
\end{tabular}

lands may be expected to be the result of river captures rather than spread via the sea (Bianco and Miller 1990).

Even that during the last 30 years freshwater ichthyofauna of Bosnia and Herzegovina was studied more intensively, still its fish fauna has not yet been systematically investigated and is under revision. Freshwater ichthyofauna of Bosnia and Herzegovina includes 108 species (Vuković 1977), with a great number of endemics (22, 20.37\%) (Vuković and Sofradžija 1986) having a restricted area of distribution. This high degree of endemicity could be attributed to historical events such geographic isolation from other European catchments, complicated geological history and climatic conditions. According to the Croatian Red Book of freshwater fish (Mrakovčić et al. 2006) and IUCN Red List of Threatened Species (Anonymous 2008) more than one-third of the endemic species there are considered as endangered. Despite its richness, for the moment there is no published list of threatened species in Bosnia and Herzegovina.

The Po brook lamprey is generally considered as threatened (Crivelli 1996) in its whole distributional range. In northern Italy it is seriously threatened and is vanishing (Bianco 1992), while in Slovenia (Povž 1995) and Croatia (Mrakovčić et al. 2006) is considered endangered. Accordingly, it is important to establish conservation measures, considering the great faunistic and scientific value of Po brook lamprey and the Hutovo Blato wetland.

\section{ACKNOWLEDGEMENTS}

The authors are thankful to Mr. Nikola Zovko (Head of the Natural Park "Hutovo Blato") for his support during the investigation. We are also thankful to Ministry of Science, Education and Sport for financial support (Projects: 001-0013077-0844, 275-0010501-0856).

\section{REFERENCES}

Anonymous 2008. 2008 IUCN Red list of threatened species. Bianco P.G. 1986. Lethenteron zanandreai (Vladykov, 1955). Pp. 237-246. In: Holčík J. (ed.), The freshwater fishes of Europe. 1/I. Petromyzontiformes. AULA-Verlag, Wiesbaden.

Bianco P.G. 1992. Zoogeographical implications of a first record of Lethenteron zanandreai on the Adriatic slope of central Italy (Cyclostomata: Petromyzontidae). Ichthyological Exploration of Freshwaters 3 (2): 183-186.

Bianco P.G. 1995. Mediterranean endemic freshwater fishes of Italy. Biological Conservation 72: 159-170. DOI: 10.1016/0006-3207(94)00078-5.

Bianco P.G., Miller P.J. 1990. Yugoslavian and other records of the Italian freshwater goby, Padogobius martensii, and a character polarization in gobioid fishes. Journal of Natural History 24: 1289-1302.

Crivelli A.J. 1996. The freshwater fish endemic to the northern Mediterranean region. An action plan for their conservation. Tour du Valat Publication, Arles, France. 
Glamuzina B., Tutman P., Buntić I., Bartulović V., Conides A. 2002. Kvalitativni sastav ihtiofaune Hutovog blata. [Qualitatively composition of Hutovo blato wetland ichthyofauna.] Pp. 38-44. In: Buntić I. (ed.) Project LIFETCY 1999/BIH035, Ministarstvo graditeljstva, prostornog uređenja i zaštite okoliša Hercegovačko-Neretvanske županijekantona, Mostar. [In Croatian.]

Holčík J. 1986. 2. Determination criteria. Pp. 24-32. In: Holčík J. (ed.) The freshwater fishes of Europe. I/I. Petromyzontiformes. AULA-Verlag, Wiesbaden.

Holčík J., Mrakovčić M. 1997. First record of Lethenteron zanandreai (Cyclostomata, Petromyzontidae) in the Adriatic basin of the Balkan peninsula and its zoogeographic consequences. Folia Zoologica 46 (3): 263-271.

Mrakovčić M., Brigić A., Buj I., Ćaleta M., Mustafić P., Zanella D. 2006. Crvena knjiga slatkovodnih riba Hrvatske. [Red Book of freshwater fish of Croatia.] Ministarstvo kulture, Državni zavod za zaštitu prirode, Republika Hrvatska, Zagreb. [In Croatian.]

Povž M. 1995. Status of freshwater fishes in the Adriatic catchment of Slovenia. Biological Conservation 72: 171-177. DOI: 10.1016/0006-3207(94)00079-6.

Tagliavini J., Tizzi R., Conterio F., Mariottini P., Gandolfi G. 1994. Mitochondrial DNA sequences in three genera of Italian lampreys. Bolletino Zoologico 61: 331-333. DOI: 10.1080/11250009409355903.

Tutman P., Glamuzina B., Bartulović V., Buntić I. 2002. Endemična ihtiofauna močvare Hutovo blato. [Endemic ichthyofauna of the Hutovo Blato wetland.] Pp. 45-48.
In: Buntić I. (ed.) Project LIFETCY 1999/BIH035, Ministarstvo graditeljstva, prostornog uređenja i zaštite okoliša Hercegovačko-Neretvanske županije-kantona, Mostar. [In Croatian.]

Vladykov V.D. 1955. Lampetra zanandreai, a new species of lamprey from Northern Italy. Copeia 1955 (3): 215-223.

Vladykov V.D., Follett W.I. 1967. The teeth of lampreys (Petromyzonidae): their terminology and use in a key of to the Holarctic genera. Journal of the Fisheries Research Board of Canada 24: 1067-1075.

Vuković T. 1977. Ribe Bosne i Hercegovine. [Fishes of the Bosnia and Herzegovina.] IGKRO «Svjetlost», Sarajevo. [In Serbo-Croatian/Croato-Serbian.]

Vuković T., Sofradžija A. 1986. Endemična ihtiofauna Bosne i Hercegovine i problemi njene zaštite. [Endemical ichthyofauna of Bosnia and Herzegovina and their conservation problems.] Pp. 39-43. In: Vuković T. (ed.) Zaštita endema $\mathrm{u}$ živom svijetu Jugoslavije. Posebna izdanja Odjeljenja prirodnih i matematičkih nauka, Akademije nauka i umjetnosti Bosne i Hercegovine. [In Serbo-Croatian/Croato-Serbian.]

Received: 14 November 2008

Accepted: 16 February 2009

Published electronically: 20 May 2009 